\title{
Educational Experiences and Shifts in Group Consciousness: Studying Women
}

\author{
Donna Henderson-King \\ Grand Valley State University \\ Abigail J. Stewart \\ University of Michigan
}

consciousness. We examine how the exposure to feminism through a women's studies course affects women's social identity and feminist consciousness.

Although it is more accurate to refer to "feminisms" to capture the plurality of opinions and theoretical perspectives expressed by contemporary feminists, one common feature across various feminist perspectives is the adoption of a pro-woman stance (Delmar, 1986). Generally speaking, feminism makes the claim that women's lives are negatively affected by discrimination and aims to improve the situation of women. Students of the women's movement have noted that one of its primary goals was to "change women's understanding of themselves, that is, to develop a sense of gender consciousness among women" (Sapiro, 1990, p. 273). One of the innovations of the women's movement was the consciousness-raising group, which emerged in both Europe and the United States (Dahlerup, 1986). Key elements of consciousness-raising groups included a nonhierarchical group structure (a leaderless group) and a focus on discovering shared features of personal experience that yielded to an analysis in structural (or gender) terms (recognizing the political in the personal) (for fuller accounts, see Freeman, 1989; Sapiro, 1990).

\footnotetext{
Authors' Note: This article is based on a doctoral thesis submitted to the University of Michigan by the first author. We thank the Society for the Psychological Study of Social Issues and the Center for the Education of Women at the University of Michigan for financial support for this research. We also thank Eaaron Henderson-King, David Winter, and several anonymous reviewers for their comments on earlier versions of this manuscript. Correspondence regarding this article should be addressed to Donna Henderson-King, Department of Psychology, Grand Valley State University, 1 Campus Drive, Allendale, MI 49401, email: hendersd@gvsu.edu.
}

PSPB, Vol. 25 No. 3, March 1999 390-399 (c) 1999 by the Society for Personality and Social Psychology, Inc. 
Despite theoretical arguments about their importance (MacKinnon, 1982), personal testimony of their power (Carden, 1974; Rowland, 1984), and research evidence confirming that testimony (Chapman, 1987; Cherniss, 1972; Nassi \& Abramowitz, 1978), women's consciousness-raising groups have faded from the social landscape of the 1980s and 1990s. Feminist scholars intentionally built some of the features of consciousness raising into women's studies courses and programs. Although women's studies was certainly not designed as a replacement for consciousness-raising groups, the decline of consciousness-raising groups has precisely paralleled the institutionalization of women's studies (Butler, Coyner, Homans, Longenecker, \& Musil, 1991; Chamberlain, 1988) and the development of feminist pedagogy (Bunch \& Pollack, 1983; Culley \& Portuges, 1985; Fisher, 1978; Maher, 1987; Schniedewind, 1987).

Thus, feminist pedagogy has built on women's experience with consciousness raising to recognize the value of integrating the personal and the intellectual along with political analysis. Feminist scholars have described the impact of sexist processes and gender blindness on knowledge generated within disciplines (see, e.g., Boxer, 1982; Farnham, 1987; Schuster \& Van Dyne, 1985) and have argued that women's studies should not only bring together knowledge across disciplines but should also explicate the links between culture, the social distribution of power, and individual woman's experiences (Klein, 1990; Stanton \& Stewart, 1995). Feminist pedagogy has tried to envision classroom practices that would support and encourage this capacity for an integration of the intellectual and emotional, the personal and the social, and the private and the political (see Maher \& Tetrault, 1994, for case studies of different classroom approaches).

In this study, we set out to assess the degree to which women's studies courses actually have the kinds of effects envisioned in feminist pedagogy and reported for consciousness-raising groups. Thus, we sought to determine whether women's studies courses increase feminist consciousness. Because the impact of these courses has been more adequately conceptualized for women students than for men (despite considerable interest in encouraging an interest in feminism among men), and because many more women than men take them, we limited ourselves to the impact of women's studies on women students.

\section{ASSESSING FEMINIST CONSCIOUSNESS}

Feminist consciousness has been defined operationally to include self-identification (as a feminist), holding feminist beliefs and values, having a variety of emotional responses (e.g., anger at sexism, pride in women), and bringing a feminist analysis to a variety of contexts (see, e.g., Bargad \& Hyde, 1991; Bartky, 1975; Crosby, 1987; Downing \& Roush, 1985; Griffin, 1989). All of these aspects of feminist consciousness-more and less intellectual or analytic, emotional, and personal-are germane to our question. Both consciousness-raising groups and feminist pedagogy have argued for the importance of integrating all of these. Thus, our assessment of changes in feminist consciousness included measures designed to tap a variety of dimensions of consciousness.

The aspects of feminist consciousness that seem most directly linked with conventional educational practices are those involving intellectual analyses of gender relations. For that reason, we included a measure of feminist analysis to assess a variety of beliefs about women's position in society and the prospects for change (see, especially, Gurin, Miller, \& Gurin, 1980; Gurin \& Townsend, 1986).

A more affectively charged set of attitudes are those associated with an analysis of women's relative position in society. Measures designed to assess the degree to which groups feel discontent about their relative social power include intellectual analysis along with an emotional response to that analysis (see, e.g., Crosby, 1987; Gurin et al., 1980).

A third measure focused on reactions not to gender roles and relations but to exposure to sexism per se. This measure, based on Bartky's (1975) incisive account of the phenomenology of women's experience when coming to terms with sexism, assesses both cognitive features of women's judgments about sexism and affective responses of uncertainty, anger, and self-doubt. Although there is anecdotal and case study evidence of these phenomenological aspects of feminist consciousness (e.g., Cherniss, 1972; Kamen, 1991; Shreve, 1989; Stewart, 1994), no systematic studies have assessed changes in these phenomenological aspects of feminist consciousness or sensitivity to sexism over time.

A fourth set of measures focused on students' affective or evaluative responses to three gender-related groups: feminists, women, and men. Women's studies, like feminism more generally, is widely believed not only to increase the warmth of women's feelings toward women and feminists but also to cool women's feelings toward men. In fact, women's studies has sometimes been accused of encouraging "male-bashing" (Miller, 1994). These evaluative responses are consistent with original formulations of social identity theory, which suggested that group consciousness would be associated with more positive evaluations of the in-group and more negative evaluations of the out-group (e.g., Tajfel, 1978a; Tajfel \& Turner, 1979). Brewer (1979) has, however, argued for the value of separating in-group favoritism from 
out-group derogation. In addition, contemporary feminist theory argues against the homogeneity of men or women and should encourage women's studies students to make distinctions among men and women.

Finally, perhaps the most personal aspect of feminist consciousness is identification of oneself as a feminist. Moreover, group identification is a classic indicator of group consciousness (Sherif \& Sherif, 1969; Tajfel, 1974).

\section{THE IMPACT OF WOMEN'S STUDIES}

\section{ON FEMINIST CONSCIOUSNESS}

Most studies of the impact of women's studies courses have focussed on one or two dimensions or variables, but the range of effects that have been demonstrated across studies supports our notion that the effects may indeed be quite diffuse. For example, Stake and Gerner (1987) reported gains in women's studies students' agentic selfesteem, job motivation, and certainty that they would attain job-related goals. Women's studies students have also reported positive changes in their interactions with others and have attributed their willingness to adopt new roles and behaviors to the impact of a women's studies course (Stake, Roades, Rose, Ellis, \& West, 1994). Cognitive effects include shifts from viewing reality as stable, deterministic, and formative of persons to viewing reality as changeable, subject to cultural and historical influence, and shaped by the person (Howe, 1985; Unger, Draper \& Pendergrass, 1986).

More directly related to changes in feminist consciousness, several studies have documented women's studies' impact on attitudes and beliefs about women and sex roles (Ruble, Croke, Frieze, \& Parsons, 1975; Scott, Richards, \& Wade, 1977; Vedovato \& Vaughter, 1980). More recent research has shown that students taking psychology of women courses in the 1980s adopted more positive and less sexist attitudes toward women (Jones \& Jacklin, 1988; O'Connell, 1989). Bargad and Hyde (1991) demonstrated that women's studies strengthened students' feminist identities. Furthermore, women's studies students have reported increased feminist activism as a result of taking a women's studies course (Stake et al., 1994) and that both their level of feminist activism and their expectations for future activism were sustained several months after taking the course (Stake \& Rose, 1994).

In addition to assessing the impact of women's studies on feminist consciousness, broadly conceived, we hoped to build on previous studies by adopting several methodological improvements that would increase our confidence in interpreting findings. First, not all studies have used longitudinal designs, which are so crucial to the inference of a change process. Second, Johnson (1982) pointed out that when studies have been longitudinal, change has often been assessed only in women's studies students; as Johnson argues, to test adequately the effect of taking a women's studies course, students taking other courses need to be included as a control group.

Third, most studies that have included control groups have simply compared women's studies students with other students not taking women's studies. However, self-selection into women's studies may be a contributing factor in changes in consciousness. As Stake and Gerner (1987) have argued, women's studies students may show changes in consciousness simply because of a predisposition or prior interest in the topic; consequently, the most appropriate control group would be students who were not taking women's studies in a given semester but who showed an interest in taking it.

Finally, most research in this area has relied on questionnaire data collected in the classroom. Although this is obviously convenient, it increases the likelihood that knowledge of the research hypotheses and social desirability will bias responses. Therefore, we took pains to contact the participants outside of the classroom setting, thus separating their course experience and their participation in the study.

\section{OVERVIEW AND HYPOTHESES}

The current research was designed to examine the effect of women's studies courses on women's feminist consciousness. Feminist consciousness was assessed at the beginning and end of the semester in two groups of students: those who took an introductory women's studies course and those who did not take such a course. This study included several methodological improvements over much of the past research in this area. It was conducted outside of the classroom and included a comparison group of students who indicated an interest in taking a women's studies course, and it assessed women's consciousness at two points in time. Furthermore, it included an assessment of the phenomenology of feminist consciousness among a broad array of measures of feminist consciousness.

We expected that women who took a women's studies course would increase in feminist consciousness across the semester, whereas women who were interested but did not take such a course would show no such change. Specifically, we expected that women who took a women's studies course would develop stronger feminist political beliefs, greater sensitivity to sexism, a stronger feminist identification, and more positive feelings toward feminists. Our expectations concerning feelings about men were less clear. Although we expected increased positivity toward feminists (and perhaps women), research from a social identity perspective 
yields conflicting results regarding the relationship between other aspects of group consciousness and evaluations of out-groups-in this case, men.

\section{METHOD}

\section{Participants}

Participants were female undergraduate students at the University of Michigan who had registered for either a history course, an English course, or one of two women's studies courses: Women's Issues or Introduction to Women's Studies. Both of the women's studies courses are introductory, and one is not sequential to the other; they offer alternative routes into the women's studies curriculum. In both courses, students are exposed to similar informational content on such topics as women's psychological and physical health issues; evidence related to women's contemporary economic status and employment experiences; a variety of perspectives on the family; important female historical and literary figures; and the social construction of gender, race, and sexuality. Both women's studies and non-women's studies students averaged 19 years of age and had an average of 2.5 years of undergraduate education. Most were Caucasian, although $20 \%$ of the women's studies students and $30 \%$ of the non-women's studies students were not.

\section{Comparison Group}

To determine whether there were differences between women's studies and non-women's studies students at the beginning of the semester, a series of $t$ tests was run on all dependent variables. The two groups differed on all measures of feminist consciousness, reaffirming the need for a comparison group that more closely fit the profile of women's studies students. To assess students' interest in women's studies, all respondents were asked on an initial questionnaire to list courses they were taking during the upcoming semester. On a second questionnaire, all were asked whether they had ever taken and whether they would be interested in taking courses in a number of different areas, including women's studies. The 41 non-women's studies students whose responses to these questions indicated any interest in women's studies but who did not actually take either of the women's studies courses that were the focus of this study (according to records from the office of the university registrar) were designated as interested students. No significant differences were found between interested and women's studies students on any measures of feminist consciousness at the beginning of the semester, indicating that interested students were a particularly appropriate comparison group.

\section{Procedure}

Prior to the beginning of the 1991 winter semester, questionnaires were mailed to the homes of the 506 undergraduate women who were registered for one of the four target courses. Questionnaires were mailed to decrease the likelihood that women's studies students would make the connection between their course enrollment and the request for their research participation. A cover letter introduced the research as a study of people's different views of the world and informed students that if they chose to participate they would receive a second questionnaire within a few months. To maximize response rate, return postage-paid envelopes were provided, a $\$ 1$ bill was attached to the first questionnaire (Biner, 1988), and students were informed that if they completed both questionnaires, they would receive personalized feedback about the study.

At the end of the semester, nearly identical follow-up questionnaires were sent to the campus addresses of the 234 women who completed and returned the initial questionnaire. Of these, 135 women responded to the second questionnaire, producing a response rate of $46 \%$ for the first wave and $58 \%$ for the second wave. This response rate seems reasonable for a relatively lengthy, two-wave questionnaire that was mailed to respondents' homes rather than administered in the classroom. Although we need to keep in mind that the final sample may have differed in some way from the initial pool, we found no differences between women who responded only to the initial questionnaire and women who responded to both questionnaires on any of the demographic variables or any of the measures of feminist consciousness considered in this article. Of the 234 first-wave respondents, $43 \%$ were enrolled in and completed a women's studies course; of the 135 women who completed both questionnaires, $46 \%$ completed a women's studies course. Among the 101 women's studies first-wave respondents, $61 \%$ also completed the second wave; among the other 133 first-wave respondents, $55 \%$ completed the second wave.

\section{Materials}

\section{FEMINIST IDENTIFICATION AND GROUP EVALUATIONS}

This research took a multifaceted approach to the measurement of feminist consciousness. Of central importance in the current study were assessments of feminist self-identification and evaluations of women, feminists, and men. We considered each of these four variables to be conceptually distinct and were interested in analyzing them separately to assess whether each had changed over time. 
Feminist identification. Using a measure based on one used in National Election Study (NES) surveys (Gurin et al., 1980), respondents were asked to consider a number of social groups (including students, workers, gays/lesbians, consumers, women, people of color, men, sororities/ fraternities, and conservatives, as well as feminists) and to write down the names of the groups to which they felt they belonged. They were then asked to indicate how much they identified with each of the groups they had specified on a scale of 1 (not at all) to 5 (very much). The score for each group ranged from 0 (the group was not specified as one to which they felt they belonged) to 5 (the group was specified, and they identified very much with that group). Test-retest reliability for feminist identification across the two waves of the questionnaire was .75 .

Group evaluations. A feelings thermometer (Miller \& Miller, 1977) was used to assess group evaluations. Using a scale of $0(\mathrm{cool})$ to $100(\mathrm{warm})$, respondents were asked to indicate how they felt about several social groups. Of particular relevance to feminist consciousness were their feelings about women, feminists, and men. Test-retest reliability for feelings about feminists over a period of approximately 4 months for this sample was .52; for feelings about women, it was .61; and for feelings about men, it was .69.

\section{PHENOMENOLOGY AND FEMINIST BELIEFS}

In addition to measures of feminist identification and group evaluations, we also included an additional set of 11 measures designed to tap women's political beliefs and their phenomenological experiences of feminist consciousness. Because there was some degree of conceptual overlap among these measures, all of them were entered into a principal components factor analysis. Results based on data from the first wave of data indicated that these measures loaded on three distinct factors (see Table 1). The measures used to tap political beliefs loaded on two separate factors-one reflecting a feminist analysis of gender relations and the other reflecting gender-related power discontent. All of the phenomenological measures designed to assess sensitivity to sexism loaded on a third factor.

Feminist analysis. An aggregate score was created from those measures that loaded together in the factor analysis described above; these were legitimacy of gender roles, legitimacy of reasons, social instability, and sense of common fate.

Two items measuring rejection of the legitimacy of traditional gender roles (e.g., "A woman's place is in the home") were borrowed from NES surveys (Gurin et al., 1980). Participants responded to each item on a 7-point scale $(1=$ disagree strongly, $7=$ agree strongly $)$, and an aver-
TABLE 1: Factor Loadings for Feminist Consciousness Measures

\begin{tabular}{lccc}
\hline & \multicolumn{3}{c}{ Factors } \\
\cline { 2 - 4 } Measures & 1 & 2 & 3 \\
\hline Legitimacy of gender roles & .09 & $\mathbf{. 6 6}$ & .25 \\
Legitimacy of reasons & -.06 &. $\mathbf{7 8}$ & .01 \\
Social instability & .30 & $\mathbf{. 5 7}$ & .19 \\
Sense of common fate & .22 & $\mathbf{. 5 8}$ & .14 \\
Power discontent/women & .13 & .12 & $\mathbf{. 8 5}$ \\
Power discontent/feminists & .16 & .18 & $\mathbf{. 8 5}$ \\
Power discontent/men & .32 & .36 & $\mathbf{. 4 5}$ \\
Double ontological shock & $\mathbf{. 5 7}$ & .45 & .06 \\
Occasion for resistance & $\mathbf{. 7 6}$ & .29 & .24 \\
Confusion & $\mathbf{. 7 6}$ & .01 & .05 \\
Wariness & $\mathbf{. 8 0}$ & .07 & .24 \\
\hline
\end{tabular}

NOTE: Bold values within each column load together on a single factor.

age score across the two items was obtained. For this and all of the following indices, scales were reversed when necessary, and in all cases, high scores indicate higher feminist consciousness.

Three additional NES (Gurin, et al., 1980) items were used to measure rejection of the legitimacy of reasons for disparities (e.g., "Men are born with more drive to be ambitious and successful than women"). The same 7point scale was used, and an average score across these items was obtained.

The perception of social instability (Tajfel, 1978b) with regard to gender relations was assessed with two items developed by the authors ("When it comes to sex roles and relations between males and females, things will always be pretty much the way they are now"; "In the future, relations between males and females could be quite different from the way they are now"). Respondents were asked to indicate their level of agreement with these statements using the same 7-point scale, and an average score across the two items was calculated.

Also included as part of this measure was Gurin and Townsend's (1986) concept of a sense of common fate with other women. Participants were asked to respond either positively or negatively to two statements about the relationship between what happens to other women, the women's movement, and what happens to them personally. Scores of 1 for no and 2 for yes were averaged across the two items.

Because these dimensions of consciousness were measured on different scales and because we wanted each dimension to be weighted equally, $z$ scores for each of these four attitudinal measures were added together so that an overall score was obtained for feminist analysis. Cronbach's alpha coefficient for feminist analysis was .65 at Time 1 and .74 at Time 2. Test-retest reliability was .59 . 
TABLE 2: Pairwise Correlations Among Dependent Variables

\begin{tabular}{|c|c|c|c|c|c|c|c|}
\hline & $\begin{array}{l}\text { Feminist } \\
\text { Analysis }\end{array}$ & $\begin{array}{c}\text { Power } \\
\text { Discontent }\end{array}$ & $\begin{array}{l}\text { Sensitivity to } \\
\text { Sexism }\end{array}$ & $\begin{array}{l}\text { Feelings About } \\
\text { Feminists }\end{array}$ & $\begin{array}{c}\text { Feelings About } \\
\text { Women }\end{array}$ & $\begin{array}{c}\text { Feelings About } \\
\text { Men }\end{array}$ & $\begin{array}{c}\text { Feminist } \\
\text { Identification }\end{array}$ \\
\hline Feminist analysis & 1.00 & $.31 *$ & $.37 * *$ & $.32 *$ & .16 & -.04 & $.31 *$ \\
\hline Power discontent & $.30 *$ & 1.00 & $.31 *$ & $.30 *$ & .06 & -.17 & $.30 *$ \\
\hline Sensitivity to sexism & .15 & $.37 * *$ & 1.00 & $.28 *$ & .04 & -.17 & $.45^{* *}$ \\
\hline Feelings about feminists & $.30 *$ & $.48 * *$ & $.30 *$ & 1.00 & $.33^{*}$ & .12 & $.50 * *$ \\
\hline Feelings about women & .14 & $.21 *$ & -.10 & $.43 * *$ & 1.00 & $.47 * *$ & .01 \\
\hline Feelings about men & -.16 & $-.26 *$ & $-.30 *$ & -.10 & $.22 *$ & 1.00 & -.16 \\
\hline Feminist identification & $.32 *$ & $.40 * *$ & $.41 * *$ & $.44 * *$ & .08 & -.22 & 1.00 \\
\hline
\end{tabular}

NOTE: Values above the diagonal are for Time 1; those below the diagonal are for Time 2.

$* p \geq .01 . * * p \geq .001$.

Power discontent. An aggregate score for power discontent was created from three separate scores, which loaded a single factor: power discontent/women, power discontent/feminists, and power discontent/men. The measure was based on one which has been used previously in NES surveys (Gurin et al., 1980). Respondents indicated how much influence they believe is held by a number of social groups using a 5-point scale ranging from -2 (far too little influence) to 2 (far too much influence), with zero meaning that the group in question has just about the right amount of influence. Thus, a high positive score on power discontent/ men meant that participants thought that men had too much social power. Data pertaining to power discontent/ women and power discontent/feminists were recoded so that a high positive score meant participants thought that women and feminists had too little social power. So that the scores for the three groups were equally weighted, the power discontent score for each group was transformed into a $z$ score. An overall score for power discontent was calculated by adding together the three $z$ scores. Cronbach's alpha coefficient for power discontent was .71 at Time 1 and .56 at Time 2. Test-retest reliability was .58 .

Sensitivity to sexism. To assess women's sensitivity to sexism, we developed items to capture four of Bartky's (1975) phenomenological experiences of feminist consciousness. Bartky's notion of double ontological shock involves women's recognition that their feminist interpretation of reality is not the only possible interpretation and the resulting uncertainty about how to interpret events (sample item: "Sometimes I'm not sure if what I'm seeing or hearing is sexist"). Wariness refers to a state of concern about the unpredictability of being exposed to sexism and with one's possible emotional reactions to it (e.g., "I sometimes feel tense because I might be confronted with something that is sexist"). Bartky also discusses how the mundane activities of life have the potential to become occasions for resistance for feminists (e.g., "Everyday occasions sometimes turn into situations in which I feel I should confront sexism and take a stand"). Furthermore, women are likely to experience a sense of confusion about how they ought to deal with specific instances of sexism (e.g., "I'm not always sure if I should confront sexism when I encounter it"). Respondents indicated their level of agreement with each statement on a 7-point scale, and an average score across this set of items was calculated as an overall score for sensitivity to sexism (see Henderson-King \& Stewart, 1997, for all 10 items in the scale). Cronbach's alpha coefficient for the scale was .84 at Time 1 and .73 at Time 2. Testretest reliability was .68 .

\section{RESULTS}

\section{Relationships among Dependent Variables}

Correlations among the dependent variables at both points in time are reported in Table 2.

\section{Repeated Measures Analyses}

To examine our hypotheses, we first ran a 2 (group: women's studies vs. interested students) x 2 (time: before vs. after course) repeated measures multivariate analysis of variance, with time as a repeated measure. The dependent variables were feminist analysis, power discontent, sensitivity to sexism, feelings about feminists, feelings about women, feelings about men, and feminist identification. We hypothesized a Group $\times$ Time interaction produced by a positive shift in feminist consciousness over time in the women's studies group and no such shift in the interested group.

The multivariate analysis of variance revealed the expected Group $\times$ Time interaction, $F(7,90)=4.73, p<$ .001. Each dependent measure of feminist consciousness was then examined using a 2 (group: women's studies vs. interested students) x 2 (time: before vs. after course) repeated measures analyses of variance (ANOVA). ${ }^{1}$ Results from univariate analyses are presented in two tables. Table 3 presents means and standard deviations for each of the feminist consciousness dependent variables at two points in time for each group of students. Table 4 pres- 
TABLE 3: Feminist Consciousness by Student Group and Time of Semester

\begin{tabular}{lccccc}
\hline \multirow{2}{*}{ Measure } & \multicolumn{2}{c}{ Women's Studies $(\mathrm{n}=62)$} & \multicolumn{2}{c}{ Interested $(\mathrm{n}=41)$} \\
\cline { 2 - 3 } \cline { 5 - 6 } & Beginning & End & & Beginning & End \\
\hline Feminist Analysis & .12 & .29 & .11 & .05 \\
& $(.62)$ & $(.42)$ & $(.56)$ & $(.61)$ \\
Power discontent & .08 & .47 & .15 & .00 \\
& $(.69)$ & $(.58)$ & $(.55)$ & $(.58)$ \\
Sensitivity to sexism & 4.67 & 4.96 & & 4.73 & 4.44 \\
& $(1.03)$ & $.95)$ & & $(.70)$ & $(.76)$ \\
Feelings about feminists & 70.57 & 77.14 & 66.10. & 64.55 \\
& $(21.80)$ & $(17.45)$ & $(20.23)$ & $(20.37)$ \\
Feelings about women & 85.69 & 88.76 & 85.08 & 85.40 \\
& $(16.73)$ & $(12.49)$ & $(14.21)$ & $(11.92)$ \\
Feelings about men & 66.67 & 66.55 & 69.55 & 70.35 \\
& $(19.28)$ & $(21.98)$ & $(18.77)$ & $(13.54)$ \\
Feminist identification & 1.97 & 2.72 & 1.90 & 1.90 \\
& $(1.90)$ & $(1.98)$ & $(1.88)$ & $(1.85)$ \\
\hline
\end{tabular}

NOTE: Values are means and standard deviations (in parentheses) from repeated measures analyses.

ents main effects, interactions, and simple effects from the repeated measures analyses.

A significant Group $\times$ Time interaction was revealed for feminist analysis, $F(1,96)=4.49, p<.04$. As expected, results indicated an increase in feminist analysis among women's studies students, $F(1,96)=5.73, p<.02$, but no change for interested students, $F(1,96)=.59$, ns.

A significant Group $\times$ Time interaction was also found for power discontent, $F(1,96)=18.43, p<.001$. Simple effects analyses revealed that power discontent increased in the women's studies group, $F(1,96)=23.76$, $p$ $<.001$, but did not change in the Interested group, $F(1$, 96) $=2.35$, ns.

There was a significant Group $\times$ Time interaction found for sensitivity to sexism, $F(1,96)=15.00, p<.001$. This interaction was due to both an increase in the levels of sensitivity in the women's studies group, $F(1,96)=$ $9.05, p<.003$, and a decrease in sensitivity in the interested group, $F(1,96)=6.44, p<.02$.

There was also a significant Group $\times$ Time interaction for feelings about feminists, $F(1,96)=4.02, p<.05$. As expected, feelings about feminists increased in the women's studies group, $F(1,96)=6.45, p<.02$, but not in the interested group, $F(1,96)=.25$, ns.

No Group $\times$ Time interaction was found for feelings about women, $F(1,96)=1.10$, ns. Nor was there an interaction for feelings about men, $F(1,96)=.09$, ns.

A significant Group $\times$ Time interaction was found for feminist identification, $F(1,96)=5.30, p<.03$. As expected, self-identification as a feminist increased in the women's studies group, $F(1,96)=12.99, p<.001$, but not the interested group, $F(1,96)=.00, n s$.

\section{DISCUSSION}

These results provide strong evidence for the effects of women's studies courses on feminist consciousness. Using a broad array of indicators of feminist consciousness, we found that students changed during the semester in which they took an introductory women's studies course. Women's studies students developed more feminist attitudes about gender relations and gender inequities in social power and influence. On a phenomenological level, they became more sensitive to sexism in their lives. They also became more positive toward feminists and more self-identified as feminist over the semester. There is, then, evidence of a coordinated shift in measures of more intellectual and more affective, more political and more private, and more social and more personal aspects of feminist consciousness.

The substantial shift in feminist identification among women's studies students is particularly noteworthy, given contemporary young women's avoidance of the feminist label (Griffin, 1989; Kamen, 1991). Although it is one thing to adopt a more positive perspective toward a group, it is yet another to embrace that group as part of one's identity. Social identity theory would predict that, in the interest of enhancing self-esteem, women's feelings about feminists would become more positive as identification with feminists increased. But how can we account for the shift in identification? Certainly exposure to a full range of feminist ideas may increase both women's understanding of the scope of feminist thought and of the congruence between their own ideas and those of feminists. Furthermore, their exposure to feminists through course material and through contact with their course instructors and facilitators may allow women's studies students to move beyond negative stereotypes of feminists and toward the adoption of a feminist identity. Future research could address the particular mechanisms that facilitate the development of this particular aspect of feminist consciousness.

There was no change over the semester in women's studies students' feelings toward women. Although social identity theory would predict a correspondent elevation in positive feelings toward women as a group because other aspects of feminist consciousness increased, no such change occurred. Women's studies students became more positive toward feminists as a group but not toward women, perhaps reflecting a more general shift toward recognizing differences among women that is encouraged by feminist scholarship. Henderson-King and Stewart (1994) have previously reported that group evaluations of feminists are more closely tied to other aspects of consciousness than are more general evalua- 
TABLE 4: Dimensions of Feminist Consciousness by Student Group and Time of Semester

\begin{tabular}{|c|c|c|c|c|c|}
\hline & Group & Time & Time Interaction & Beginning & End \\
\hline Feminist analysis & $\mathrm{WS}=\mathrm{Int}$. & $2=1$ & WS increased & $\mathrm{WS}=\mathrm{Int}$. & WS $>$ Int. \\
\hline Power discontent & $\mathrm{WS}=\mathrm{Int}$ & $2=1$ & WS increased & $\mathrm{WS}=\mathrm{Int}$ & $\mathrm{WS}>$ Int. \\
\hline Sensitivity to sexism & $\mathrm{WS}=\mathrm{Int}$ & $2=1$ & WS increased/int. decreased & $\mathrm{WS}=\mathrm{Int}$ & $\mathrm{WS}>$ Int. \\
\hline Feelings about feminists & WS $>$ Int. & $2=1$ & WS increased & WS = Int. & $\mathrm{WS}>$ Int \\
\hline Feelings about women & $\mathrm{WS}=\mathrm{Int}$. & $2=1$ & None & & \\
\hline Feelings about men & $\mathrm{WS}=\mathrm{Int}$ & $2=1$ & None & & \\
\hline Feminist identification & $\mathrm{WS}=\mathrm{Int}$ & $2>1$ & WS increased & $\mathrm{WS}=\mathrm{Int}$ & WS $>$ Int. \\
\hline
\end{tabular}

NOTE: WS = women's studies student group; Int. = interested student group.

tions of women; results from the current research extend these findings.

Similarly, the women's studies students in this study showed no shift in their evaluations of men. Although they became more feminist, these women did not become more negative toward men as a group. These results are in line both with Brewer's (1979) argument that intergroup bias is not the result of out-group derogation and with contemporary feminist theoretical efforts to recognize the heterogeneity of gender groups. In addition, these findings counter fears that women's studies courses cool women's feelings toward men.

An unexpected finding in this study was that just as women's studies students were becoming more sensitive about sexism, interested students were actually becoming less so. Although we initiated this research with an eye to examining the particular effects of exposure to feminism through women's studies, we are also alerted to the effects of not taking women's studies courses. Although a college or university education has long been considered to have liberalizing effects on students' political ideologies (e.g., Alwin, Cohen, \& Newcomb, 1991; Anderson \& Bryjak, 1989; Astin, 1993; Feldman \& Newcomb, 1969), there have been several findings that suggest a shift away from this trend. For example, recent findings indicate that shifts over the 4 years of undergraduate education toward a more liberal worldview are not as large as have previously been found (Dey, 1989; Wilder, Hoyt, Surbeck, Wilder, \& Carney, 1986). More directly related to gender, Holland and Eisenhart (1990) recently found a dramatic shift in both Black and White women's aspirations and values over the course of their undergraduate education, with early strong career orientations replaced by priorities of romance and attraction at the end of 4 years. Thus, it may be that the contemporary educational environment is not as liberalizing as it once was, perhaps especially with regard to gender roles. The present results regarding sensitivity to sexism suggest that women's studies courses not only increase feminist consciousness among students, but they may also serve to buffer the erosion of feminist consciousness in a climate that may be becoming less liberal.

One possible limitation to this study lies in the possibility that the women's studies students who did not participate in the second wave may have declined to participate precisely because they did not like the course. Furthermore, feminist consciousness in these students may not have increased (and may even have decreased), as it did among those who responded to the second questionnaire. Thus, it may be that the increases found in feminist consciousness in this sample appear artificially high because the group who responded did so because of their enjoyment of the course and subsequent interest in the topic. Although this is clearly possible, it is unlikely. First, the questionnaire was administered outside of the classroom, and students did not know their participation was in any way linked to their enrollment in the course. Students who had not enjoyed the course would not, therefore, have withheld participation as a statement of their displeasure with the course. Furthermore, any students who strongly disliked the course may have been as likely as students who enjoyed the course to respond to the questionnaire because it gave them the opportunity to vent negative feelings about feminism and feminists.

A second limitation of the present study is that it fails to consider how permanent these changes in feminist consciousness might be. Whereas there clearly were increases in feminist consciousness across the semester, we do not know anything about the duration of the effects. On one hand, it might be argued that short-term increases in feminist consciousness would begin to wane among students who were no longer exposed to feminist perspectives on a regular basis. On the other hand, because the women in this study were, as young adults, at a developmental stage in which they were engaging in identity formation, changes in group consciousness could have a longer-lasting effect because these changes may have been incorporated into their sense of identity (Stewart \& Healy, 1989). Although data from the current study are unable to shed light on this question, future re- 
search should consider how durable the range of effects found in this study might be.

\section{CONCLUSION}

This study's methodological improvements on much of the past research in this area include having administered the survey instrument outside the classroom as well as using a particularly relevant comparison group. The findings provide strong evidence of the efficacy of introductory women's studies courses in raising feminist consciousness in women's studies students. The findings also suggest that participation in a women's studies course does more than facilitate the development of feminist consciousness; to some degree, it may also serve as a buffer against the erosion of feminist consciousness. In future research, it will be important to explore the efficacy of women's studies courses for promoting feminist consciousness-and buffering its erosion-in male students. Specific psychological effects of other educational experiences related to social diversity and intergroup relations, as well as the duration of educational effects, should also be examined.

\section{NOTE}

1. In one of the introductory courses, small discussion groups were facilitated by more advanced students. The number of students in these groups was too small to test for group differences. The other course was collectively taught by a group of four graduate student instructors who held separate discussion sections. We tested for the effect of instructor on change across the semester for these four groups and found no significant differences among them.

\section{REFERENCES}

Alwin, D. F., Cohen, R. L., \& Newcomb, T. M. (1991). Political attitudes over the life span: The Bennington women after fifty years. Madison: University of Wisconsin Press.

Anderson, J. B., \& Bryjak, G. J. (1989). Out of the tower and into the street: University students and social justice issues. Educational Research Quarterly, 13, 47-56.

Astin, A. W. (1993). What matters in college: Four critical years revisited. San Francisco: Jossey-Bass.

Bargad, A., \& Hyde, J. S. (1991). Women's studies: A study of feminist identity development in women. Psychology of Women Quarterly, 15, 181-202.

Bartky, S. L. (1975). Toward a phenomenology of feminist consciousness. Social Theory and Practice, 3(4), 425-439.

Biner, P. M. (1988). Effects of cover letter appeal and monetary incentives on survey response: A reactance theory application. Basic and Applied Social Psychology, 9(2), 99-106.

Boxer, M. (1982). For and about women: They theory and practice of women's studies in the U.S. Signs, 7, 661-695.

Brewer, M. B. (1979). Ingroup bias in the minimal intergroup situation: A cognitive-motivational analysis. Psychological Bulletin, 86, 307-324.

Bunch, C., \& Pollack, S. (1983). Learning our way: Essays in feminist education. Trumansburg, NY: The Crossing Press.

Butler, J. E., Coyner, S., Homans, M., Longenecker, M., \& Musil, C. T. (1991). Liberal learning and the women's studies major: A report to the profession for the National Women's Studies Association. College Park, MD: National Women's Studies Association.
Carden, M. L. (1974). The new feminist movement. New York: Russell Sage Foundation.

Chamberlain, M. (Ed.). (1988). Women in academe: Progress and prospects. New York: Russell Sage Foundation.

Chapman, J. (1987). Adult socialization and out-group politicization: An empirical study of consciousness-raising. British Journal of Political Science, 17, 315-340.

Cherniss, C. (1972). Personality and ideology: A personological study of women's liberation. Psychiatry, 35, 109-125.

Crosby, F. J. (1987). The denial of personal disadvantage among you, me, and all the other ostriches. In M. Crawford \& M. Gentry (Eds.), Gender and thought. New York: Springer-Verlag.

Cross, W. E. (1971). The Negro-to-Black conversion experience. Black World, 20, 13-27.

Culley, M., \& Portuges, C. (Eds.). (1985). Gendered subjects: The dynamics of feminist teaching. London: Routledge \& Kegan Paul.

Dahlerup, D. (1986). The new women's movement: Feminism and political power in Europe and the U.S.A. Beverly Hills, CA: Sage.

Delmar, R. (1986). What is feminism? In J. Mitchell \& A. Oakley (Eds.), What is feminism? (pp. 8-33). Oxford, UK: Basil Blackwell.

Dey, E. (1989). College impact and student liberalism revisited: The effect of student peers. Unpublished manuscript, University of California, Los Angeles, Graduate School of Education, Higher Education Research.

Downing, N. E., \& Roush, K. L. (1985). From passive acceptance to active commitment: A model of feminist identity development for women. The Counseling Psychologist, 13(4), 695-709.

Farnham, C. (Ed.). (1987). The impact of feminist research in the academy. Bloomington: Indiana University Press.

Feldman, K. A., \& Newcomb, T. M. (1969). The impact of college: Epilogue. In K. Feldman \& T. Newcomb (Eds.), The impact of college on students (Vol. 1, pp. 325-338). San Francisco: Jossey-Bass.

Fisher, B. (1978). What is feminist pedagogy? Radical Teacher, 6, 18, 20-25.

Freeman, J. (1989). Feminist organization and activities from suffrage to women's liberation. In J. Freeman (Ed.), Women: A feminist perspective (4th ed., pp. 541-555). Mountain View, CA: Mayfield.

Griffin, C. (1989). "I'm not a women's libber but...": Feminism, consciousness and identity. In S. Skevington \& D. Baker (Eds.), The social identity of women (pp. 173-193). London: Sage Ltd.

Gurin, P., Miller, A. H., \& Gurin, G. (1980). Stratum identification and consciousness. Social Psychology Quarterly, 43, 30-47.

Gurin, P., \& Townsend, A. (1986). Properties of gender identity and their implications for gender consciousness. British Journal of Social Psychology, 25, 139-148.

Henderson-King, D. H., \& Stewart, A. J. (1994). Women or feminists: Assessing women's group consciousness. Sex Roles, 31, 505-516.

Henderson-King, D. H., \& Stewart, A. J. (1997). Feminist consciousness: Perspectives on women's experience. Personality and Social Psychology Bulletin, 23, 415-426.

Holland, D. C., \& Eisenhart, M. A. (1990). Educated in romance: Women, achievement, and college culture. Chicago: University of Chicago Press.

Howe, K. G. (1985). The psychological impact of a women's studies course. Women's Studies Quarterly, 13, 23-24.

Johnson, M. (1982). Research on teaching the psychology of women. Psychology of Women Quarterly, 7, 96-104.

Jones, G. P., \& Jacklin, C. N. (1988). Changes in sexist attitudes toward women during introductory women's and men's studies courses. Sex Roles, 18, 611-622.

Kamen, P. (1991). Feminist fatale: Voices from the "twentysomething" generation explore the future of the "Women's Movement." New York: Donald I. Fine.

Klein, J. T. (1990). Interdisciplinarity: History, theory and practice. Detroit: Wayne State University Press.

MacKinnon, C. A. (1982). Feminism, Marxism, method and the state: An agenda for theory. Signs, 7, 515-544.

Maher, F. (1987). Toward a richer theory of feminist pedagogy. Journal of Education, 169, 91-99.

Maher, F. A., \& Tetrault, M.K.T. (1994). The feminist classroom. New York: Basic. 
Miller, M. M. (1994). "You're going to be the only guy in there": Men's minority experience in Introduction to Women's Studies. NWSA Journal, 6, 452-467.

Miller, W. E., \& Miller, A. H. (1977). The CPS 1976 National Election Study. Ann Arbor, MI: Inter-University Consortium for Political and Social Research.

Nassi, A. J., \& Abramowitz, S. I. (1978). Raising consciousness about women's groups: Process and outcome research. Psychology of Women Quarterly, 3, 139-156.

O'Connell, A. N. (1989). Psychology of women students' self-concepts, attitudes, and assertiveness: A decade of research. Teaching of Psychology, 16(4), 178-181.

Rowland, R. (1984). Women who do and women who don't join the women's movement. London: Routledge \& Kegan Paul.

Ruble, D., Croke, J., Frieze, I., \& Parsons, J. (1975). A field study of sexrole attitude change in college women. Journal of Applied Social Psychology, 5(2), 110-117.

Sapiro, V. (1990). The women's movement and the creation of gender consciousness: Social movements as socialization agents. In $\mathrm{O}$. Ichilov (Ed.), Political socialization, citizenship education, and democracy (pp. 266-280). New York: Teachers College Press.

Schniedewind, N. (1987). Teaching feminist process. Women's Studies Quarterly, 15, 15-31.

Schuster, M., \& Van Dyne, S. (1985). Women's place in the academy. Totowa, NJ: Rowman \& Allenheld.

Scott, R., Richards, A., \& Wade, M. (1977). Women's studies as change agents. Psychology of Women Quarterly, 1, 377-379.

Sherif, M. (1966). In common predicament: Social psychology of intergroup conflict and cooperation. Boston: Houghton Mifflin.

Sherif, M., \& Sherif, C. W. (1969). Social psychology. New York: Harper \& Row.

Shreve, A. (1989). Women together, women alone. New York: Ballantine Books.

Stake, J. E., \& Gerner, M. A. (1987). The women's studies experience: Personal and professional gains for women and men. Psychology of Women Quarterly, 11, 277-284.

Stake, J. E., Roades, L., Rose, S., Ellis, L., \& West, C. (1994). The women's studies experience: Impetus for feminist activism. Psychology of Women Quarterly, 18, 17-24.
Stake, J. E., \& Rose, S. (1994). The long-term impact of women's studies on students' personal lives and political activism. Psychology of Women Quarterly, 18, 403-412.

Stanton, D., \& Stewart, A.J. (1995). Feminisms in the academy. Ann Arbor: University of Michigan Press.

Stewart, A. J. (1994). The women's movement and women's lives: Linking individual development and social events. In A. Lieblich \& R. Josselson (Eds.), The narrative study of lives: Exploring identity and gender (pp. 230-250). Thousand Oaks, CA: Sage.

Stewart, A. J., \& Healy, J. M. Jr. (1989). Linking individual development and social changes. American Psychologist, 44, 30-42.

Tajfel, H. (1974). Social identity and intergroup behaviour. Social Science Information, 13(2), 65-93.

Tajfel, H. (1978a). Differentiation between social groups: Studies in the social psychology of intergroup relations. London: Academic Press.

Tajfel, H. (1978b). The social psychology of minorities (Report No. 38). London: Minority Rights Group.

Tajfel, H. (1982). Social psychology of intergroup relations. Annual Review of Psychology, 33, 1-39.

Tajfel, H., \& Turner, J. C. (1979). An integrative theory of intergroup conflict. In S. Worchel \& W. G. Austin (Eds.), The social psychology of intergroup relations (pp. 33-47). Monterey, CA: Brooks-Cole.

Tajfel, H., \& Turner, J. C. (1986). The social identity theory of intergroup behavior. In S. Worchel \& W. G. Austin (Eds.), Psychology of intergroup relations (pp. 7-24). Chicago: Nelson-Hall.

Unger, R. K., Draper, R. D., \& Pendergrass, M. L. (1986). Personal epistemology and personal experience. Journal of Social Issues, 42, 67-79.

Vedovato, S., \& Vaughter, R. M. (1980). Psychology of women courses changing sexist and sex-typed attitudes. Psychology of Women Quarterly, 4, 587-590.

Wilder, D. H., Hoyt, A. E., Surbeck, B. S., Wilder, J. C., \& Carney, P. A. (1986). Greek affiliation and attitude change in college students. Journal of College Student Personnel, 27, 510-519.

Received November 25, 1996

Revision accepted April 2, 1998 